\title{
Praktik Jual Beli Jagung dengan Sistem Tebasan di Desa Triwung Lor Kecamatan Kademangan Kota Probolinggo Perspektif Akad Juzäf
}

\author{
Azizatul Mahmudah \\ Institut Keislaman Abdullah Faqih Gresik \\ Email:icacaao1@gmail.com \\ Bakhrul Huda \\ UIN Sunan Ampel Surabaya \\ Email: bakhrulhuda@gmail.com
}

\begin{abstract}
The practice of buying and selling corn with the wholesale system has been understood from generation to generation by the Muslim community in Triwung Lor village, Kademangan sub-district, Probolinggo City. This kind of buying and selling practice is carried out naturally and is not based on knowledge of religious teachings. Researchers are interested in uncovering this phenomenon with a fiqh analysis tool, namely the juzâf contract, because the majority of Triwung Lor villagers are Muslim and they must know their muamalah activities, that is, according to their Islamic teachings or not. This research reveals that the practice of buying and selling corn using the wholesale system carried out by the Muslim community in Triwung Lor village, Kademangan district, Probolinggo City tends to have fulfilled the juzajf sale and purchase agreement. That is the buying and selling that is allowed plural by fiqh scholars for objects that cause mashaqqab (difficulties) and have become a necessity for the majority of the community because of the ease of doing so.
\end{abstract}

Key Words: Corn; buy and sell; wholesale; jurää;

\begin{abstract}
Abstrak: Praktik jual beli Jagung dengan sistem tebasan telah makhlum dilakukan secara turun temurun oleh masyarakat Muslim di desa Triwung Lor kecamatan Kademangan Kota Probolinggo. Praktik jual beli semacam ini dilakukan secara natural dan tidak berlandaskan pengetahuan ajaran agama. Peneliti tertarik mengungkap fenomena ini dengan alat analisis fikih yaitu akad $j u z \bar{a} f$ sebab mayoritas masyarakat desa Triwung Lor beragama Islam dan mereka harus mengetahui akan aktifitas muamalah mereka, yaitu sesuai dengan ajaran Islam yang mereka anut atau tidak. Penelitian ini mengungkapkan bahwa praktik jual beli Jagung dengan sistem tebasan yang dilakukan oleh masyarakat Muslim di desa Triwung Lor kecamatan Kademangan Kota Probolinggo cenderung telah memenuhi akad jual beli ju₹ă $f$. Yaitu jual beli yang diperbolehkan secara jamak oleh para ulama fikih untuk objek yang menimbulkan mashaqqah (kesulitan) dan telah menjadi kebutuhan mayoritas masyarakat sebab kemudahan dalam melakukannya.
\end{abstract}

Kata Kunci: Jagung; jual beli; tebasan; juгāf; 


\section{PENDAHULUAN}

Ajaran Islam mencakup segala aspek kehidupan umat manusia, di mana aspek satu dengan lainnya saling berkaitan dan ada dialektika. Dialektika ekonomi dewasa ini sering dikaitkan dengan akidah dan etika keislaman. Utamanya sejak semakin sadarnya masyarakat untuk belajar norma dan nilai Agama Islam. Berbagai akademisi dan praktisi mencoba mengkaji dan mereview kegiatan ekonomi yang ada tentang kesesuaian dan ketidaksesuaiannya dengan ajaran Islam.

Praktik ekonomi (khususnya jual beli) yang dilakukan oleh kaum Muslim di Indonesia mayoritas berdasar pada adat dan kebiasaan turun temurun yang cenderung tidak melihat nilai atau etika Islam yang ada. Sebagai kaum Muslim perlu memahami dengan seksama akan etika jual beli Islam sebab ranah jual beli merupakan lahan yang dapat mendatangkan keberkahan sebagaimana sabda Rasulullah saw. ${ }^{1}$ Karena itu praktek jual beli seyogyanya dilakukan menurut perspektif Fikih yang merupakan ilmu Islam yang mengkaji tentang hukum dan etika bermuamalah (bertransaksi), dari situ akan diketahui akan batasan-batasan Islam yang harus dilakukan oleh umat Muslim.

Berbagai bentuk jual beli dipraktikkan oleh kaum Muslim Indonesia, salah satunya adalah jual beli sistem tebasan. Sistem tebasan sering dipraktekkan dalam kehidupan kaum Muslim yang mata pencaharian berprofesi sebagai petani. Dalam jual beli sistem tebasan ini kebanyakan dilakukan oleh para petani yang memiliki persawahan milik sendiri dan bukan dari lahan persawahan hasil sewa. Salah satu contoh kaum Muslim Indonesia yang mempraktekan praktik jual beli dengan sistem tebasan adalah masyarakat desa Triwung Lor kecamatan Kademangan Kota Probolinggo, di mana mata pencaharian mereka adalah bertani menanam Jagung.

Desa Triwung Lor termasuk wilayah Kecamatan Kademangan yang menghasilkan Jagung yang cukup tinggi, edafologi dan luas area persawahan di daerah tersebut memungkinkan bagi para petani untuk menanam Jagung, Padi, Sayuran ataupun Umbi-umbian dengan baik. Dan dalam objek studi ini peneliti mengkhususkan pada jual beli tebasan Jagung di wilayah tersebut yang kondisinya masih masih berada di pohonnya. Hal yang menjadi pertimbangan bagi peneliti mengapa tertarik untuk meneliti praktik jual beli tanaman Jagung sistem tebasan, dikarenakan realitanya dalam praktik tersebut objek yang menjadi jual beli masih di pohon dan tanaman Jagung masih terbungkus di dalam daun yang belum siap panen. Hal ini menjadi problema tersendiri dalam jual beli Jagung dengan sistem tebasan ini sebab ketidakjelasan kualitas dan kelaikan Jagung yang diperjualbelikan. Dalam

${ }^{1}$ Ahmad b. Ali b. Hajar al-Asqalani, Fatḥ al-Bārī Vol. 4 No. Hadis 2004 (Kairo: Dār al-Rayyān, 1986), 385.

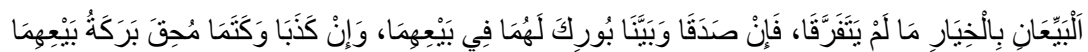

"Penjual dan pembeli masing-masing memiliki hak pilih (khiyar) selama keduanya belum berpisah. Bila keduanya berlaku jujur dan saling terus terang, maka keduanya akan memperoleh keberkahan dalam transaksi tersebut. Sebaliknya, bila keduanya berlaku dusta dan saling menutup-nutupi, niscaya akan hilanglah keberkahan pada transaksi mereka berdua"

Dalam Abdullah Muhammad b. Yazid b. Majah al-Rabi'i al-Qazwini, Sunan Ibn Mäjah Vol. 2 (Beirut: Dār al-Fikr, t.th), 768:

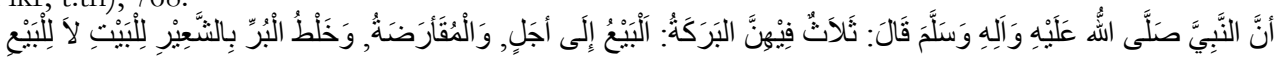

Nabi saw. bersabda, "ada tiga hal yang mengandung berkah jual beli tidak secara tunai, muqaradhah (mudharabah), dan mencampur gandum dengan jewawut untuk keperluan rumah tangga sendiri, bukan untuk dijual."

el-Qisț: Journal of Islamic Economics and Business (JIEB)

Vol. 10 No. 2 Oktober 2020 
ajaran Islam salah satu syarat sahnya jual beli adalah mengetahui objek yang diperdagangkan dengan jelas, tidak samar baik zat, bentuk, sifat, dan harganya. ${ }^{2}$

Pelaksanaan jual beli Jagung beserta pohon dan daunnya dengan sistem tebasan ini melalui berbagai tahapan. Tahap pertama ketika Jagung masih berumur seratus hari atau tiga bulan sepuluh hari, penebas sudah mendatangi pemilik sawah untuk menawarkan diri sebagai pembeli. Jika kedua belah pihak setuju maka kedua belah pihak tersebut melakukan tawar menawar harga, jika cocok dan saling ridha. Maka penebas telah mempunyai hak untuk membeli tanaman Jagung tersebut. Petani yang menjual dengan sistem tebasan daunnya sudah dipangkas terlebih dahulu, agar dapat dilihat hasil tanaman Jagung oleh pembeli. ${ }^{3}$

Jika kalkulasi yang dilakukan calon pembeli (penebas) menunjukkan bagus, maka ia akan mendatangi rumah petani pemilik lahan. Jika ada kecocokan di antara keduanya saat itu maka muncullah negosiasi dan di akhiri dengan perjanjian yang ditetapkan saat itu juga. Tahap negosiasi harga ini dilakukan pada saat tanaman Jagung dalam keadaan masih di pohon atau saat perjanjian (persetujuan) jual beli tersebut dengan membayar DP (down payment) duapuluh persen dari harga yang sudah ditetapkan oleh kedua belah pihak yang selanjutnya pembayaran sisa dilakukan secara kontan satu hari sebelum panen. ${ }^{4}$

Jual beli tanaman Jagung dengan sistem tebasan yang terjadi di desa Triwung Lor menggunakan sistem perkiraan (penaksiran) atau dalam ajaran Islam dapat dipadankan dengan jual beli al-Juzāf, yang berarti sistem prediksi atau perkiraan. ${ }^{5}$ Menurut Imam Syaukani al-Juzāf merupakan sesuatu yang tidak diketahui kadarnya (kuantitasnya) secara detail. ${ }^{6}$ Penaksiran yang dilakukan oleh masyarakat desa Triwung Lor dengan menggunakan luas sawah dengan banyak yang digunakan. Juga bisa dengan mengitari sawah kemudian dengan memegang atau membuka bungkus tongkol Jagung yang digunakan sampel untuk memperkirakan jumlah seluruh hasil panen tanaman Jagung. ${ }^{7}$

Praktik waktu penaksiran sangat mempengaruhi hasil penaksiran, jika saat menaksir masih belum jelas wujudnya, kemungkinan terjadi salah taksir sebab ditakutkan ada hama dan kekeringan yang melanda. Berbeda dengan menaksir saat wujudnya sudah jelas, warnanya sudah merah atau menguning dan dapat diperkirakan dan diprediksi hasilnya mengenai takaran dan timbangannya. ${ }^{8}$ Maka permasalahan yang dapat timbul dari jual beli Jagung sistem tebasan ini adalah penebas membeli Jagung yang masih terlalu lama untuk dipanen, sehingga dapat menyebabkan kerugian bagi penebas. Jagung yang masih belum siap panen dan belum mengetahui kualitas hasil panen tanaman tersebut. Umumnya walaupun tidak dilakukan secara menyeluruh, dalam jual beli sistem tebasan ini, penebas mengambil beberapa sampel dari tanaman Jagung yang akan diperjualbelikan, lalu memprediksi atas dasar sampel tersebut apakah Jagung yang akan dibeli sesuai kriterianya atau tidak.

Maka dari gambaran di atas memperlihatkan akan kesenjangan antara teori dan praktik jual beli perspektif ajaran Islam. Disinyalir bahwa jual beli seperti ini

2 Shobirin, 'Jual Beli dalam Pandangan Islam”, Jurnal Bisnis dan Manajemen Islam-BISNIS, Vol. 3, No. 2, 2015, 260

${ }^{3}$ Hasan, Penebas, Wawancara, Probolinggo, 15 Januari 2020.

${ }^{4}$ Ibid.

${ }^{5}$ Wahbah al-Zuhaili, "Figh Islam wa Adillatuhu Bab Jual Beli”, Jilid 5 (Damaskus Dar al-Fikr 2005), 290

${ }^{6}$ Ibid., 291.

${ }^{7}$ Hasan, Penebas, Wawancara, Probolinggo, 15 Januari, 2020

${ }^{8}$ Wahbah al-Zuhaili, "Fiqh Islam ...", 295. el-Qisț: Journal of Islamic Economics and Business (JIEB) 
adalah jual beli barang atau sesuatu yang tidak jelas wujudnya. Dan Nabi Saw. telah melarang jual beli yang mengandung unsur gharar sebagaimana yang disampaikan oleh para ahli fikih dengan berdasar pada hadis:

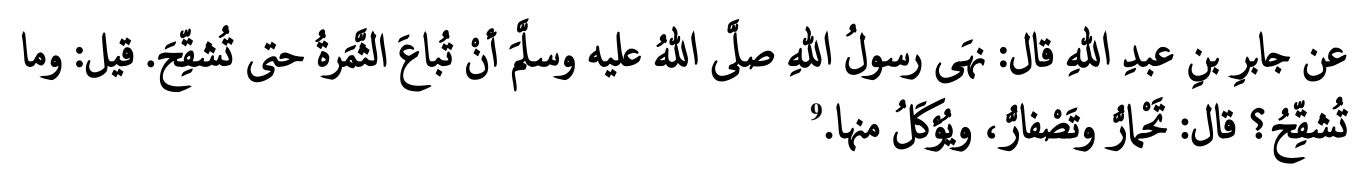

Diriwayatkan dari sahabat Jabir b. Abdillah ra.; "Nabi Saw. telah melarang menjual buah kurma hingga ia telah berwarna merah atau kuning dan laik untuk dimakan".

Berdasarkan hal di atas, kami merasa perlu untuk mengadakan penelitian terhadap jual beli tanaman Jagung dengan sistem tebasan yang terjadi di Desa Triwung Lor Kecamatan Kademangan Kota Probolinggo perspektif akad al-Juzāf.

\section{METODE PENELITIAN}

Jenis penelitian ini menggunakan metode penelitian kualitatif normatif deskriptif. Dikatakan kualitatif sebab terma yang menjadi objek penelitian adalah sebuah fenomena berupa proses kejadian. Normatif sebab alat analisis yang peneliti gunakan adalah norma hukum fikih. Dan deskriptif sebab penelitian ini menggunakan teknik pengumpulan data secara triangulasi (gabungan) antar observasi, wawancara, dan kajian pustaka untuk mendeskripsikan dan menggambarkan lebih dalam tentang kondisi, objek dan fenomena sosial yang teliti, yaitu berkaitan dengan segala sesuatu yang dilakukan oleh subjek penelitian.

Dalam penelitian ini peneliti melakukan pengamatan (observasi) langsung, sehingga dapat mengatahui secara kongkrit kondisi dan kejadian di lingkungan yang menjadi lokasi penelitian. Peneliti terjun ke lapangan sendiri pada tahap focused and selection yang menjadi objek, melakukan pengumpulan data lewat wawancara pada subjek-subjek penelitian yaitu para penebas dan petani serta kajian pustaka terkait desa, aktifitas pertanian dan kitab-kitab fikih yang relevan sebagai alat analisis data yang ada. Kemudian peneliti menganalisis data-data yang ada dan membuat kesimpulan yang objektif.

\footnotetext{
${ }^{9}$ Muhammad b. Ismail al-Bukhari, Șaḥị̣ al-Bukhārī Vol. 2 No. Hadis 2084 (Kairo: Dār Ibn Kathīr, 1993), 766.

Dalam redaksi matan Hadis yang lain riwayat Anas b. Malik dalam Șaḥh al-Bukhärì disebutkan:

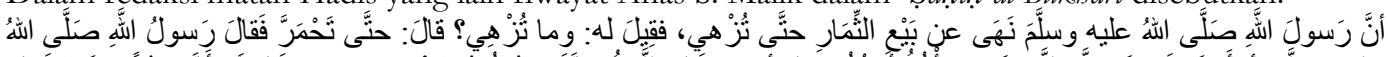

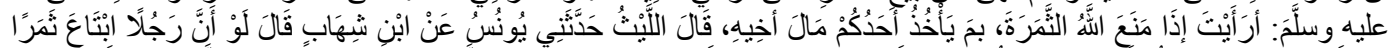

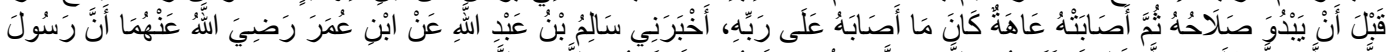

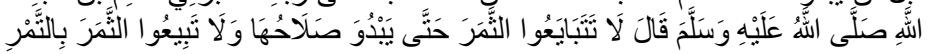
"sesungguhnya Nabi saw. melarang menjual buah-buah Kurma hingga ia laik. Ada yang bertanya; keadaan laik itu bagaimana?. Beliau saw menjawab; sampai ia berwarna kemerah-merahan. Kemudian Nabi saw. bersabda; "Coba renungkanlah, bagaimana sekiranya Allah swt. mencegah Kurma menjadi masak hanya dikarenakan salah seorang di antara kalian mengambil harta saudaranya!". Imam al-Laits berkata; telah menceritakan kepada saya Yunus dari Ibnu Syihab yang berkata: "Seandainya seseorang menjual buah sebelum nampak kebaikannya kemudian terserang hama (penyakit) maka tanggung jawabnya adalah pada pemiliknya (yang punya lahan, si penjual buah sebelum laik masa panen)". Telah mengabarkan kepada saya Salim bin 'Abdullah dari (ayahnya) sahabat Ibnu'Umar ra. bahwa Nabi saw. bersabda: "Janganlah kalian saling berjual beli buah-buahan hingga tampak kebaikannya dan jangan pula menjual kurma matang dengan kurma mentah".
}

el-Qisț: Journal of Islamic Economics and Business (JIEB)

Vol. 10 No. 2 Oktober 2020 


\section{PRAKTIK JUAL BELI JAGUNG DENGAN SISTEM TEBASAN}

Desa Triwung Lor merupakan salah satu Desa di Kecamatan Kademangan yang sebagian besar masyarakat bekerja sebagai petani. ${ }^{10}$ Kondisi geografis wilayah Triwung Lor secara umum merupakan wilayah persawahan, luas wilayah Desa Triwung Lor adalah 196,45 Ha. Berada di ketinggian 10 meter di atas permukaan laut dengan curah hujan terkecil $18 \mathrm{~mm}$ dan tertinggi $344 \mathrm{~mm} .{ }^{11}$

Persawahan yang ada di desa Triwung Lor sebagian besar menanam tanaman Jagung. Dalam setahun tanaman Jagung bisa dua kali tanam dan dua kali panen dengan masa waktu kurang lebih empat bulan. Selain tanaman Jagung para petani juga menanam padi dengan kisaran waktu tiga bulan lebih. ${ }^{12}$ Tanaman Jagung sangat cocok ditanam di iklam yang panas, maka Jagung menjadi pilihan yang tepat bagi para petani untuk membudidayakan di musim kemarau. ${ }^{13}$ Jika kondisi tanah yang terlalu kering juga dapat membuat tanaman mati. Sehingga Jagung membutuhkan penyinaran penuh dari matahari dengan kecukupan air yang sedang, tidak kurang dan tidak lebih. ${ }^{14}$ Sedangkan cuaca yang bagus untuk menanam padi ketika musim penghujan, karena padi membutuhkan air yang banyak dibandingkan Jagung. ${ }^{15}$

Banyak masyarakat di desa Triwung Lor lebih tertarik menanam Jagung karena biaya operasionalnya cukup murah dan laba penjualan yang cukup tinggi. Untuk melengkapi data yang lebih akurat peneliti mewawancarai Bapak Hasan sebagai penebas. Peneliti mendapatkan rekomendasi dari Bapak Tanto mengenai Bapak Hasan saat peneliti melakukan wawancara mengenai tanaman Jagung. Peneliti sedang bersama bapak Hasan di gudang Jagung milik bapak Hasan. Melakukan wawancara pada tanggal 10 juni 2020 sehari setelah mewawancari bapak Tanto. Bapak Hasan menyampaikan tentang latar belakang terjadinya praktik sistem tebasan:

"Sebenarnya semua tanaman itu bisa dijualbelikan dengan sistem tebasan, hanya saja saya memilih untuk membeli tanaman Jagung, karena penjualan tanaman Jagung lebih banyak peminatnya dibandingkan tanaman lain. Saya sudah 20thn bekerja sebagai penebas, disitu banyak sekali alasan terjadinya petani menjual tanaman Jagung dengan sistem tebasan. Salah satu alasan petani menjual tanaman jagung karena untuk meringankan proses panen. Yang mana petani tidak mau susah payah mengeluarkan uang lagi saat panen. Ada juga alasan karena tidak mau repot dengan aktivitas pengilingan dan penjemuran Jagung selama tiga sampai empat hari di bawah sinar matahari. Ketika tanaman Jagung sudah cukup umur untuk dijual tebasan, petani menghubungi saya untuk melihat Jagungnya, jika cocok akan terjadi transaksi jual beli sistem tebasan". ${ }^{16}$

Dengan banyaknya jumlah penduduk desa yang berprofesi sebagai petani, maka banyak transaksi jual beli yang terjadi di desa Triwung Lor tersebut. Dan salah

10 Tim Penulis, Profil Desa Triwung Lor Kecamatan Kademangan Kota Probolinggo (Probolinggo,

Dokumentasi Desa, t.th.), 8-9

11 Ibid.

12 Bambang, Petani, Wawancara, Probolinggo, 13 Juni 2020

${ }^{13}$ Hasan, Penebas, Wawancara, Probolinggo 10 Juni 2020.

${ }^{14} \mathrm{http}: / /$ www.Pioner.com/web/site/Indonesia/Berita-Umum/Cara-Menanam-Jagung-di-Musim-

Kemarau/, diakses tanggal 12 Juni 2020.

15 Tim Penulis, Profil Desa Trimung Lor..., 9.

${ }^{16}$ Hasan, Penebas, Wawancara, Probolinggo, 10 Juni 2020. 
satu jenis transaksi jual beli yang ada adalah transaksi jual beli tanaman Jagung dengan sistem tebasan. Jual beli dengan sistem tebasan adalah suatu rutinitas jual beli yang dilakukan masyarakat desa Triwung Lor kecamatan Kademangan kota Probolinggo dalam melakukan penjualan hasil pertanian berupa tanaman Jagung. Masyarakat Triwung Lor melakukan transaksi sistem tebasan untuk mempermudah petani menjual hasil panennya. Tidak banyak waktu, biaya ataupun tenaga. Hal ini sebagaimana disampaikan oleh Bapak Bambang:

"Jual beli tanaman Jagung dengan sistem tebasan sangat memudahkan saya sebagai petani, karena saya tidak repot melakukan proses penggilangan dan penjemuran. Saya hanya melakukan proses penanaman sampai Jagung sudah layak untuk dijual tebas kepada penebas. Kira-kira batang Jagung sampai berwarna agak kecoklatan. Pada sistem tebasan juga memudahkan saya dalam mekanisme pemanenan. Saat panen saya tidak perlu mencari tenaga buruh panen, karena tenaga kerja saat proses panen sudah ditanggung penebas. Alat transportasi dan yang lainnya saat proses panen juga sudah ditanggung oleh penebas. Karena itu saya lebih suka menjual dengan sistem tebasan. Disamping karena tidak merepotkan dalam proses panen sampai penjemuran. Juga meringankan beban saya jika saya sedang butuh uang."17

Bapak Hasan dan Bapak Tanto yang menjadi subjek penelitian menyampaikan alur penjualan dan praktik tanaman Jagung dengan sistem tebasan kami deskripsikan sebagaimana berikut:

a. Subjek dan Objek Jual Beli Tebasan

Pelaku yang melakukan jual beli tanaman Jagung dengan sistem tebasan merupakan masyarakat Desa Triwung Lor itu sendiri, baik si petani, pemanen, sampai dengan si penebasnya. Penebas ini seperti pemborong yang membeli tanaman jagung yang masih belum siap panen. Sebelum mereka berdua melakukan sistem tebasan. Mereka harus sudah paham dan mengerti tentang jual beli sistem tebasan dan harus saling percaya satu sama lain. Selain Jagung, objek sistem tebasan ini bisa jadi tanaman padi, umbi-umbian dan lainnya. Khusus Jagung, objek yang diperjualbelikan masih dalam keadaan 95- 110 hari atau saat tanaman Jagung masih berada di pohon dan masih belum siap panen. Petani menjual tanaman Jagung ketika daun Jagung berwarna coklat agak kehijauan. Saat berumur 95-110 hari, warna biji tanaman Jagung masih berwarna agak kekuningan. Warna yang bagus untuk panen saat biji Jagung berwana orenge tua hingga kemerah-merahan. Untuk masa panen harus menunggu 15-20 hari dari masa penjualan dengan sistem tebasan. Saat waktu panen tiba warna batang dan daun Jagung sudah berwarna coklat. Penjualan tanaman Jagung ini dilakukan pada musim kemarau, karena tanaman Jagung tidak banyak membutuhkan air sehingga cocok ditanam saat musim kemarau. ${ }^{18}$

\section{b. Cara Menghubungi Pihak yang Bersangkutan}

Cara ketika petani ingin menjual tanaman Jagungnya dengan sistem tebasan di desa Triwung Lor ini dilakukan tanpa makelar, langsung antara penebas dan petani. Petani menghubungi penebas untuk melihat langsung tanaman Jagung di

${ }_{17}$ Bambang, Petani, Wawancara, Probolinggo, 13 Juni 2020

${ }^{18}$ Hasan, Penebas, Wawancara, Probolinggo, 10 Juni 2020 el-Qisț: Journal of Islamic Economics and Business (JIEB) 
sawah milik petani. Saat penebas sedang berada di sawah milik petani, yang dilakukan oleh penebas adalah melakukan survei terhadap tanaman Jagung. ${ }^{19}$

c. Cara Melakukan Perjanjian

Mengenai perjanjian jual beli tanaman Jagung dengan sistem tebasan ini tidak ada perjanjian tertulis. Praktik ini pada umumnya hanya menggunakan lisan saja yang didasari kepercayaan antara petani dan penebas. Petani atau pemilik sawah melakukan kesepakatan secara lisan dengan mengatakan, "saya jual Jagung ini kepadamu", lalu si penebas menjawab, "saya beli Jagung ini darimu", atau dengan bahasa dengan redaksi berbeda namun punya esensi yang sama. Jadi pasca adanya ijab qabul bil lisan ini menandakan bahwa jagung tersebut sudah menjadi milik si penebas. Namun ketika ada kerugian di akhir saat waktu panen, si penebas meminta keringanan kepada petani untuk menanggung bersama kerugian tersebut dengan cara mengurangi harga jual Jagung dari yang disepakati di awal. Menurut pengakuan Tanto, salah satu penebas; "selama saya membeli tanaman Jagung dengan sistem tebasan, jarang sekali mendapatkan kerugian, karena Jagung yang dijual kepada saya sudah cukup bagus (laik) untuk menunggu masa panen." 20

\section{d. Cara Kesepakatan Harga}

Tahap penentuan harga dilakukan saat penebas telah melakukan survei di sawah milik petani. Penebas akan menemui si petani untuk negosiasi harga yang disepakati bersama. Sebagian besar petani meminta uang panjar terlebih dahulu kepada penebas lalu sisa pembayaran akan dilunasi di akhir penjualan (pasca panen). Dalam melakukan penetapan harga beli saat negosiasi, penebas menetapkan harga beli Jagung dengan menggunakan perkiraan hasil panen Jagung sesuai sampel yang diperoleh. Cara perhitungan penebas menggunakan luas sawah dengan banyak bibit yang digunakan. Juga bisa dengan cara menglilingi luas sawah. Pemilihan bibit juga mempengaruhi tongkol Jagung, semakin bagus bibit maka tongkol Jagung semakin bagus dan harga jualnya juga tinggi. Dalam hal ini Hasan menyampaikan:

"saya biasanya menghitung tanaman Jagung sistem tebasan ada dua pilihan. Pilihan pertama bagi bibit yang bagus dan hasil juga bagus saya perkirakan 20.000 tongkol dengan luas sawah $4.000 \mathrm{~m}^{2}$, dengan pilihan kedua 16.000 tongkol untuk bibit kurang bagus dan hasil yang kurang bagus dengan luas sawah $4.000 \mathrm{~m}^{2}$. Perhitungan $1 \mathrm{~kg}$ Jangung memuat 6 tongkol Jagung. Saya beri contoh penghitungan sistem tebasan untuk sawah berukuran $4.000 \mathrm{~m}^{2}$. Penghitungan dengan tongkol yang bagus yaitu 20.000 tongkol. Cara penghitungan $\frac{20.000 \text { tongkol }}{6 \text { tongkol }}=3.333$ ton.

Hasil dari pengitungan dikalikan dengan harga Jagung saat ini. 3.333 ton $\times 3.400=$ 11.333.333 dan dibulatkan menjadi 11.334.000. Harga yang sudah saya hitung tidak lagsung diberitahukan kepada petani karena harga ini masih dikurangi dengan biaya panen, biaya penggilingan dan penjemuran. Dalam pengurangan harga minimal 1.000.000. Jadi $11.334 .000-1.000 .000=10.334 .000$. Jadi harga 10.334.000 itu yang diberitahukan kepada petani. Dari harga itu petani saling tawar menawar dengan saya. Karena ada petani yang tidak mau potongan harga untuk proses panen dikurangi terlalu banyak. Dan dari harga itu juga saya mendapatkan laba, meskipun laba yang saya dapatkan tidak begitu banyak. Jika harga sudah

19 Ibid.

20 Tanto, Penebas, Wawancara, Probolinggo, 09 Juni 2020 
sepakat maka saya membayar $20 \%$ kepada petani. $20 \%$ ini pembayaran dimuka kepada petani."21

e. Cara Melakukan Penyerahan Tanaman Jagung

Penyerahan tanaman Jagung yang digunakan Hasan selaku penebas ialah ketika sudah membeli tanaman Jagung milik petani, tanaman Jagung tidak sepenuhnya milik penebas. Karena tanaman Jagung masih belum siap panen. Dalam perawatan tanaman Jagung yang masih belum siap panen ditanggung perawatannya oleh petani. ${ }^{22}$ Penyerahan yang dilakukan saat panen tiba. Saat panen semua tanaman Jagung sudah milik penebas, karena sesuai dengan perjanjian awal. Ketika panen tiba semua tanaman Jagung sudah menjadi milik penebas.

Kesepakatan yang dibuat oleh petani dan penebas hingga tanaman Jagung itu dipanen, biaya panen, tenaga kerja dan sampai proses penggilingan semua ditanggung oleh penebas atau pembeli. Jika tanaman Jagung selesai dipanen dan diserahkannya uang pembayaran tersisa pada petani, maka berakhirlah perjanjian transaksi yang dilakukan.

\section{f. Cara Pembayaran Dalam Sistem Tebasan}

Sistem tebasan di desa Triwung Lor melakukan pembayaran dengan bayar di awal (panjer) atau DP dan pelunasan di akhir perjanjian. Penebas dan petani sudah saling percaya dalam transaksi ini. Saat awal terjadi perjanjian penebas menawarkan kepada petani untuk pembayaran dengan DP dan melunasi di akhir perjanjian dengan syarat penebas yang menentukan jumlah DP. Penebas yang beli tanaman Jagung di desa Triwung Lor Kecamatan Kademangan Kota Probolinggo biasanya menggunakan DP sebanyak 20\% dari harga yang ditetapkan, selebihnya akan dilunasi jika Jagung sudah selesai dipanen. Pelunasan ini juga sebagai tanda berakhirnya transaksi yang dilakukan.

\section{ANALISIS HUKUM FIKIH TERHADAP PRAKTEK JUAL BELI JAGUNG DENGAN SISTEM TEBASAN}

Para Ulama' membagi macam-macam jual beli menjadi beberapa bentuk, yaitu ditinjau dari rukun, syarat, objek dan hukum jual beli. Wahbah secara garis besar membaginya menjadi dua yaitu;

a) Ditinjau dari sisi hukum jual beli. ulama' Hanafi mengemukakan hukum jual beli menjadi tiga, yaitu:

1) Jual beli yang sah, jual beli yang sah dapat dikatakan kegiatan jual beli yang memenuhi syari'at Islam.

2) Jual beli batal, jual beli yang batal menurut syari'at Islam, salah satu dari rukun atau syarat tidak terpenuhi yang menyebabkan jual beli batal.

3) Jual beli yang rusak (fasid), jual beli ini dilakukan oleh orang yang layak pada barang yang layak, tetapi mengandung sifat yang tidak diinginkan oleh syariah, seperti menjual barang yang tidak jelas.

Sedangkan selain ulama Hanafi hanya membaginya menjadi dua yaitu:

1) Jual beli sah, jual beli sah adalah transaksi yang memenuhi syarat dan rukun jual beli.

${ }^{21}$ Hasan, Penebas, Wawancara, Probolinggo, 10 Juni 2020

22 Ibid. 
2) Jual beli tidak sah, jual beli tidak sah adalah dimana salah satu rukun atau syaratnya tidak terpenuhi dan tidak memenuhi pengaruh hukum. ${ }^{23}$

b) Ditinjau dari sisi objek jual belinya, yaitu dari barang yang dipertukarkan maka akad jual beli terbagi menjadi tiga macam:

1) Sistem barter

Sistem barter yaitu pertukaran benda atau barang tertentu dengan benda atau barang milik orang lain. Seperti menukar jam dengan sepatu.

2) Jual beli salam (memesan barang)

Jual beli salam yaitu jual beli yang penerimaan barangnya ditangguhkan dengan pembayaran tunai. Artinya untuk membayar harga didepan dan pengiriman barang terspesifikasi untuk masa yang akan datang yang telah ditentukan.

3) Jual beli șarf

Jual beli șarf yaitu tukar menukar uang dengan uang. Seperti menukar uang dengan riil. 24

Dalam konsep jual beli tanaman Jagung dengan sistem tebasan di desa Triwung Lor kecamatan Kademangan kota Probolinggo sendiri, secara praktik jual beli yang dilakukan dengan sistem tebasan, rukun jual belinya telah terpenuhi, yaitu adanya dua orang yang saling berakad (yaitu penjual/petani dan pembeli/penebas), objek dagangan (yaitu jagung) dan ijab qabul. Kaitannya dalam syarat jual beli, di mana syarat dua orang yang bertransaksi harus berakal, baligh dan tidak dalam tekanan (ikrāh) juga telah terpenuhi sebab baik petani dan penebas tidak dalam tekanan saat transaksi dan keduanya terbilang sudah dewasa dan mengerti akan setiap konsekuensi tindakannya. Syarat akan ijab qabul di mana dalam madzhab Syafi'i secara mu'tamad harus diucapkan juga telah dipenuhi di mana antara petani dan penebas ada transaksi terucap dengan jelas yang dipahami di antara mereka berdua.

Sedangkan syarat objek dagangan yang harus dimiliki sepenuhnya oleh petani saat akan dijual, barangnya bermanfaat, jelas kadar ukuran secara keseluruhannya dapat dikatakan bahwa syarat terakhir tentang jelasnya kadar ukuran secara keseluruhannya belum sepenuhnya terpenuhi sebab penebas hanya bisa mentaksir dan memperkirakan objek yang ia akan beli yaitu tanaman Jagung yang masih belum siap panen dengan kisaran umur 95-110 hari.

Penjualan tanaman Jagung menggunakan sistem tebasan, yang mana sistem tebasan adalah memborong hasil tanaman sebelum dipanen atau dipetik dengan kondisi tanaman Jagung yang dijual kondisinya masih relatif belum laik panen atau mendekati masa panennya. Maka jika merujuk pada Hadis Nabi saw. dalam Hadis riwayat sahabat Jabir sebelumnya ${ }^{25}$ dapat dikatakan bahwa jual beli sistem tebasan ini termasuk yang dilarang oleh Nabi saw. Namun jika menurut pengakuan salah satu subjek penelitian, Tanto, di mana ia sebagai penebas selalu membeli tanaman yang sudah terlihat mulai mematang (cukup laik) dan tinggal menunggu masa

\footnotetext{
${ }^{23}$ Wahbah al-Zuhaili, "Fiqh Islam ...,", 237.

24 Ibid., 238.

${ }^{25}$ Muhammad b. Ismail al-Bukhari, Șaḥịh al-Bukhārī Vol. 2 No. Hadis 2084 (Kairo: Dār Ibn Kathīr, 1993), 766. 
panennya secara laik betul, maka ia dapat dikatakan keluar dari khițāb larangan Nabi saw. tersebut.

Kondisi Tanto yang menebas Jagung yang sudah terlihat laik dan tinggal tunggu masa panen sejenak agar lebih laik panen seutuhnya tersebut dapat digambarkan sebagai kurma yang sudah mulai memerah walau belum siap dimakan. Praktik jual beli tanaman Jagung dengan sistem tebasan dijual saat batang Jagung sampai berwarna agak kecoklatan atau kondisi menjual tanaman Jagung menunggu siap panen seutuhnya, yaitu saat tanaman Jagung sudah tidak perlu perawatan kembali dan hanya menunggu hasil panen saja. ${ }^{26}$

Terdapat beberapa pendapat menurut para Imam Mazhab sebagai berikut:

1. Menurut Imam Syafi'I

Membolehkan menjual tanaman yang belum siap panen, dengan syarat tanaman itu langsung dipotong dari pohonnya dan tidak boleh menundanunda. ${ }^{27}$

2. Menurut Imam Maliki

Diperbolehkan menjual tanaman yang belum siap panen, kecuali tanaman itu sudah menguning dan mendekati waktu panen. Dengan syarat harus memotong tanaman dari pohonnya dan tidak boleh menunda-nunda. ${ }^{28}$

3. Menurut Imam Hanbali

Tidak boleh menjual tanaman sampai waktu panen..$^{29}$

4. Menurut Imam Hanafi

Menjual tanaman yang belum siap panen sah, jika tanaman itu bisa dibedakan dengan bunganya, bisa dilihat bagus dan rusaknya. Dan tidak ada syarat memotongnya. ${ }^{30}$

Dalam praktik jual beli tanaman Jagung di desa Triwung Lor ini dilakukan pada saat tanaman Jagung telah berumur 95-110 hari dan kondisi tanaman Jagung yang dijual sudah cukup laik panen. Karena dilihat dari batang, daun dan biji tanaman Jagung yang sudah baik untuk siap tunggu masa panen yang lebih laik. Saat pembelianpun tidak perlu perawatan lagi hanya saja menunggu tanaman Jagung siap untuk panen. Jadi jual beli tanaman Jagung dengan sistem tebasan di desa Triwung Lor kecamatan Kademangan kota Probolinggo sah perspektif Imam Hanafi, sebab tanaman Jagung yang dijual sudah laik panen dan dianggap tidak bertentangan dengan Hadis sebelumnya.

Jual beli tebasan dapat juga dikaitkan atau disebut sebagai jual beli juzāf (taksiran). Menurut Imam Syaukani, al-Juzāf merupakan sesuatu yang tidak diketahui kadarnya (kualitasnya) secara detail. ${ }^{31}$ Pada dasarnya syarat jual beli adalah objek dagangan harus diketahui kadar ukuran secara keseluruhan secara jelas, dan jual beli juzāf ini termasuk jual beli yang dikecualikan dan termasuk hal yang darūrat sebab memenuhi kebutuhan masyarakat akan transaksi yang mudah, ${ }^{32}$

\footnotetext{
${ }^{26}$ Hasan, Penebas, Wawancara, Probolinggo, 09 Juni 2020

27 Zakariya b. Muhammad al-Anshari, Fath al-W ahhab bisharh Minhäj al-Tulläb (Bairut: Dār al-kutub alIlmiyah, 2010), 311.

28 Abd Rahman al-Jazari, Alā Maẓāhib al-Arba’ah (Lebanon: Dār al-Kutub al-Ilmiyah, 2003), 266.

${ }^{29}$ Ibid., 270

30 Ibid., 269

${ }^{31}$ Ibid., 270

${ }^{32}$ Wahbah al-Zuhaili, “Figh Islam ...”, 291
} 
dan mayoritas para ahli fikih membolehkan jual beli juzāf pada barang dagangan yang sulit diketahui kadar timbangan, bilangan dan jenisnya secara pasti. ${ }^{33}$

Praktik yang dilakukan oleh masyarakat desa Triwung Lor pada umumnya menjual Jagung yang masih ada di pohonnya dan dianggap sudah cukup laik panen. Pada transaksi tersebut dijual dengan model perkiraan menggunakan sampel, observasi tanaman yang ada dan luas tanah. Pengambilan sampel oleh penebas dengan cara mengitari satu petak sawah milik petani, menghitung luas sawah, dan membuka bungkus tongkol tanaman Jagung, jika berwarna merah maka jagung sudah bagus dan cukup laik untuk ditunggu beberapa hari untuk siap panen.

Dalam jual beli Juzāf sendiri terdapat beberapa syarat yang harus dipenuhi menurut fuqāh $\bar{a}^{\prime}$ Malikiyah, yaitu: ${ }^{34}$

1. Objek yang dijual harus terlihat ketika akad jual beli. Jual beli tanaman Jagung ini objek yang digunakan adalah Jagung.

Saat penebas mendatangi petani untuk survei Jagung maka pada saat itu juga penebas mengetahui kondisi objek yang akan dibeli. Syarat ini juga disampaikan oleh ulama Syafi'iyah dan Hanabilah.

2. Penjual dan pembeli tidak mengetahui secara detail ukuran, bilangan dan berat barang yang dijual.

Saat petani menjual Jagung kepada penebas dengan umur tanaman yang masih belum sepenuhnya siap panen, petani dan penebas tidak mengetahui secara pasti akan kualitas tanaman Jagung saat itu. Sebab tanaman Jagung dilapisi dengan kulit Jagung dan penebas hanya melihat sampel secara acak dari lahan.

3. Jual beli Juzāf bertujuan membeli dalam jumlah banyak (borongan) dan tidak satuan (ecer). Di sini ulama fikih menggarisbawahi bahwa selagi objek dagangan itu dapat dihitung dengan kongkrit dan dapat dijual satuan tanpa ada mashaqqah maka tidak boleh dijual secara juzāf.

Jual beli tanaman Jagung dengan sistem tebasan dalam kasus yang di angkat ini menggunakan sistem borongan, tidak terbilang satuan.

4. Barang yang dijual dapat ditaksir oleh orang yang ahli (juru) taksir, maka tidaklah sah jual beli secara juzāf untuk barang yang sulit ditaksir.

Dalam praktik jual beli tanaman Jagung, penebas dapat menaksir menggunakan pengakuan petani tentang berapa banyak bibit yang telah ditanam, luas area lahan dan sampel yang diambil secara acak di lahan saat observasi. Sehingga dari situ penebas bisa menaksir Jagung yang akan dibeli. Secara historis dan praktik di lapangan menunjukkan bahwa para penebas merupakan orang ahli taksir, sehingga perkiraan yang dilakukan oleh penebas selalu mendekati kebenaran.

5. Barang yang dijual berjumlah banyak atau sangat besar.

Jual beli tanaman Jagung yang dilakukan oleh petani dan penebas berjumlah banyak yang hanya mampu dihitung dengan taksiran sebab sulit dan menyusahkan jika harus dihitung secara kiloan atau satuan.

6. Ratanya tanah yang digunakan untuk menjual barang dagangan. Hal ini dimaksutkan agar tidak ada salah taksir sebab keadaan geografi yang cekung dan seterusnya.

Tanaman Jagung yang dijual petani kepada penebas di desa Triwung Lor ditanam di sawah yang terbilang rata tanahnya.

${ }^{33}$ Hisam al-Din Afanah, Kitāb al-Fiqh al-Täjir al-Muslim (Palestina: Dār al-Ṭīb li al-Ṭabā‘ah wa al-Nashr, 2005), 100.

${ }^{34}$ Ibid., 592-593. 
7. Tidak boleh menggabungkan jual beli barang yang diketahui kadarnya secara jelas dengan barang yang tidak diketahui kadarnya secara jelas. Dalam praktik jual beli tanaman Jagung ini tidak menggabungkan jual beli yang tidak jelas kadarnya dengan yang jelas kadarnya.

Dengan demikian transaksi jual beli tanaman Jagung yang dilakukan oleh masyarakat desa Triwung Lor yang tidak diketahui jumlahnya dengan menggunakan perkiraan dan taksiran memenuhi akad jual beli juzāf. Hal ini sebab ketujuh syarat di atas telah terpenuhi dan nyata dilakukan oleh masyarakat setempat.

Kemudian dalam praktik jual beli tanaman Jagung dengan sistem tebasan yang dilakukan oleh masyarakat desa Triwung Lor yang menggunakan pembayaran Down Of Payment (DP) tidak mempengaruhi keabsahan akad juzāf. Fatwa DSN-MUI nomer 13/DSN-MUI/IX/2000 menyatakan bahwa para ulama membenarkan tentang permintaan uang muka dalam akad jual beli. Dan oleh karena itu sistem pembayaran yang dilakukan oleh masyarakat desa Triwung Lor diperbolehkan karena aturan Islam yang disampaikan dalam fatwa DSN-MUI memperbolehkan tentang pembayaran secara angsur dalam akad jual beli.

Dengan demikian bahwa jual beli Jagung dengan sistem tebasan yang sudah menjadi kebiasaan tahunan penduduk desa Triwung Lor yang tidak menimbulkan keresahan dan masalah baik sebelum dilakukan kesepakatan atau sesudahnya dapat dibenarkan perspektif akad juzāf. Kalaupun ada salah taksir yang mengakibatkan kerugian yang nampak bagi penebas, antara penjual (petani) dan pembeli (penebas) telah ada saling keridhaan dan toleransi keringanan untuk membayar sisa harga beli yang sudah dijanjikan sebelumnya.

\section{PENUTUP}

Berdasarkan penelitian ini, maka model muamalah masyarakat desa Triwung Lor tentang hasil tani berupa Jagung yang dijual kepada penebas dengan sistem tebasan memenuhi akad jual beli juzāf perspektif madzhab Maliki. Jual beli juzāf merupakan salah satu bentuk jual beli yang dibolehkan sebab ada unsur kebutuhan mendesak dan adanya mashaqqah. Maka jika para petani atau pemilik lahan tanaman Jagung tidak merasa ada mashaqqah, hendaknya menjual hasil pertaniannya ketika sudah panen saja atau dengan jual kering sesuai beratnya. Dengan menggunakan timbangan yang kongkrit ketika sudah melewati proses penjemuran selama 3 sampai 4 hari.

Untuk menghindari hal yang tidak diinginkan dan untuk memenuhi apa yang telah tertera dalam al-Qur'an [2]: 282, seyogyanya petani dan penebas melakukan perjanjian jual beli dengan sistem tebasan tersebut secara tertulis dan ada dua saksi terpercaya. Hal ini untuk menghindari hal-hal yang tidak diinginkan di kemudian.

\section{DAFTAR PUSTAKA}

Al-Qur'ān al-Karìm

Afanah, Hisam al-Din. Kitāb al-Fiqh al-Tājir al-Muslim. Palestin: Dār al-Ṭīb li alTabā'ah wa al-Nashr, 2005.

Ansari (al), Zakariya b. Muhammad. Fatḥ al-Wahhāb bisharh Minhāj al-Tullāb. Bairut: Dār al-Kutub al-Ilmiyah, 2010.

Asqalani (al), Ahmad b. Ali b. Hajar. Fatḥ al-Bārī. Kairo: Dār al-Rayyān, 1986.

Bambang, Petani, Wawancara, Probolinggo, 13 Juni 2020.

Bukhari (al), Muhammad b. Ismail. Șahīh al-Bukhārī. Kairo: Dār Ibn Kathīr, 1993.

Fatwa DSN-MUI nomer 13/DSN-MUI/IX/2000

el-Qisț: Journal of Islamic Economics and Business (JIEB) 
Hasan, Penebas, Wawancara, Probolinggo, 15 Januari 2020.

http://www.Pioner.com/web/site/Indonesia/Berita-Umum/Cara-Menanam\agung-di-Musim-Kemarau/, diakses tanggal 12 Juni 2020

Jazari (al), Abdul Rahman. Alā Maz̄āhib al-Arba'ah. Lebanon: Dār al-Kutub al-Ilmiyah, 2003.

Qazwini (al), Abdullah Muhammad b. Yazid b. Majah al-Rabi'i. Sunan Ibn Mājah. Beirut: Dār al-Fikr, t.th.

Penulis, Tim. Profil Desa Triwung Lor Kecamatan Kademangan Kota Probolinggo. Probolinggo, Dokumentasi Desa, t.th.

Tanto, Penebas, Wawancara, Probolinggo, 09 Juni 2020

Shobirin, "Jual Beli dalam Pandangan Islam", Jurnal Bisnis dan Manajemen IslamBISNIS, Vol. 3, No. 2, 2015

Zuhaili (al), Wahbah. Fiqh al-Islām wa Adillatuhu. Damaskus: Dār al-Fikr, 2005. 